\title{
洏慢性杀球体腎炎の臨床病理学的研究
}

\begin{tabular}{|c|c|c|c|c|c|}
\hline \multicolumn{5}{|c|}{ 福島県立医科大学楠内科教室 } & \\
\hline & 土信田宏治, & 佣木 & 智男, & 尾形 & 茂夫 \\
\hline & 高木善三郎, & 本宿 & 尚, & 鈴木 & \\
\hline & 咲子，佐々木とし子 & 安居: & F賀子， & 斎藤 & \\
\hline & 和市, 井上 & 末永 & 守， & 高橋 & \\
\hline & 恕, & 鈴木 & 邦夫, & 井口 & \\
\hline
\end{tabular}

\section{A CLINICAL AND PATHOLOGICAL STUDY ON DIFFUSE GLOMERULONEPHRITIS}

BY

\author{
Nobuo Kusunoki, Kōji Toshida, Tomoo Maseki, Shigeo Ogata, Yõ Yamagata \\ Zenzaburō Takagi, Takashi Honshuku, Hisa Suzuki, Sakiko Igari \\ Toshiko Sasaki, Chikako Yasui, Haruko Saito,, Waici Sano \\ Tatsuya Inoue, Mamoru Suenaga, Kazuhiko Takahashi \\ Hiroshi Ichimura, Sachi Kakinomoto \\ Kunio Suzuki and Katsuo Iguchi
}

The Third Department of Internal Medicine, Fukushima Medical College

(Prof.: N. Kusunoki)

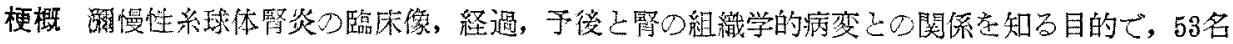

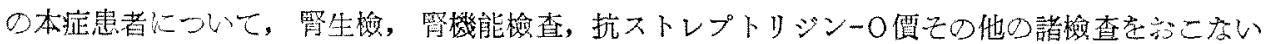

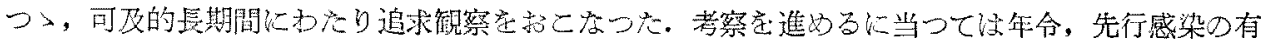

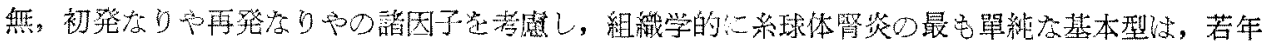

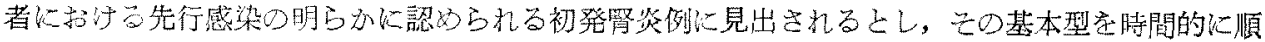

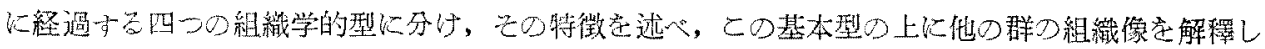

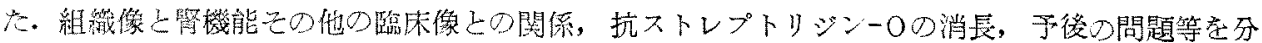

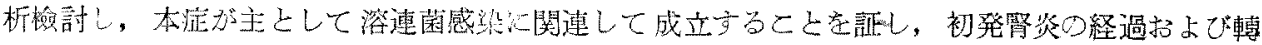

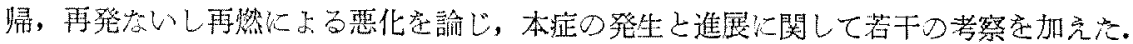

沉発性腎疾患に関する知見はVolhard および Fahr の卓見以来，しばらくはいちじるしい進歩 を来なさなかつたが，近年病態生理学的研究が大

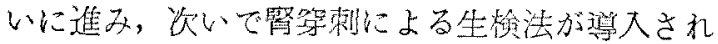
て以来，この力面の知見の躍進は，まことにめざ ましいものがある。ことに最近は生检材料の電顕
的研究が進み，婜疾患あるいは腎機能と霄の微細 種造との関連等に関する問題は日ましに解明され つ〉ある。婜生蚞による系球体腎炎に関する観察 は，今日すでに少なから好数に達するが，こと に本邦に沶いて盛んなる感がある(Parrish1),

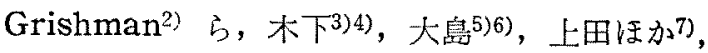


坂口ほ办8)，Vernier ${ }^{9)}$ )ら。著者方も本問題に関 し数次の報告10) 13)をしてきたが，本論文におい ては腎生娭像を基盤とする臨床病理学的な観察を 述べ，あ放せて本症の登生と進展について若叮の 考察を試みた。

\section{被検材料および検查方法}

本論文に扔いて材料としたものは洒慢性系球估 腎炎の入院患者53名です心て筒生検もしくは剖 検によつて病理縕織学的診断を確毞したもので り，その観察期間は最も長いものでは入院外来を 通じやく 5 年に達する。こ扎らの症例中にはネフ ローゼ症候群の列はひとまず含ませないことっし な.GFRはマニトールを名つて, RPFiPAH

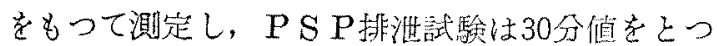
た.Antistreptolysin-O洒注自㒸製打よび北研
製 Streptolysin-O 使用, Rantz-Randall の方 法に徒つて測定した。

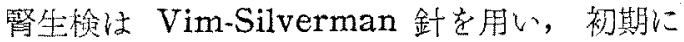
は腰捏位で方こなつたが，之の後はすへて腹卧位 で腹部に枕をあてつ㧍こなつた。得られた留切 片估直ちに Susa 液にて固定し, H.E., Azan, PAS, Elastica-Van Gieson なだの染色を施し

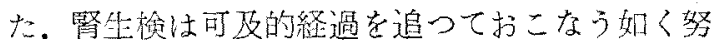
わた。得られた切片の中に糸球体数コ以上を含

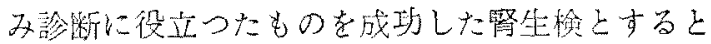
き，53名中成功した腎生横1回の例は34名，2回 は14名，3回は3名であつた。剖桧2名である。

\section{実験成績}

53症例の主なる所見を一括表示すると第1表索 得名。表中，組織学的所見注第1回生榆時主たは

Table 1. Clinical and Pathological Findings of the Patients

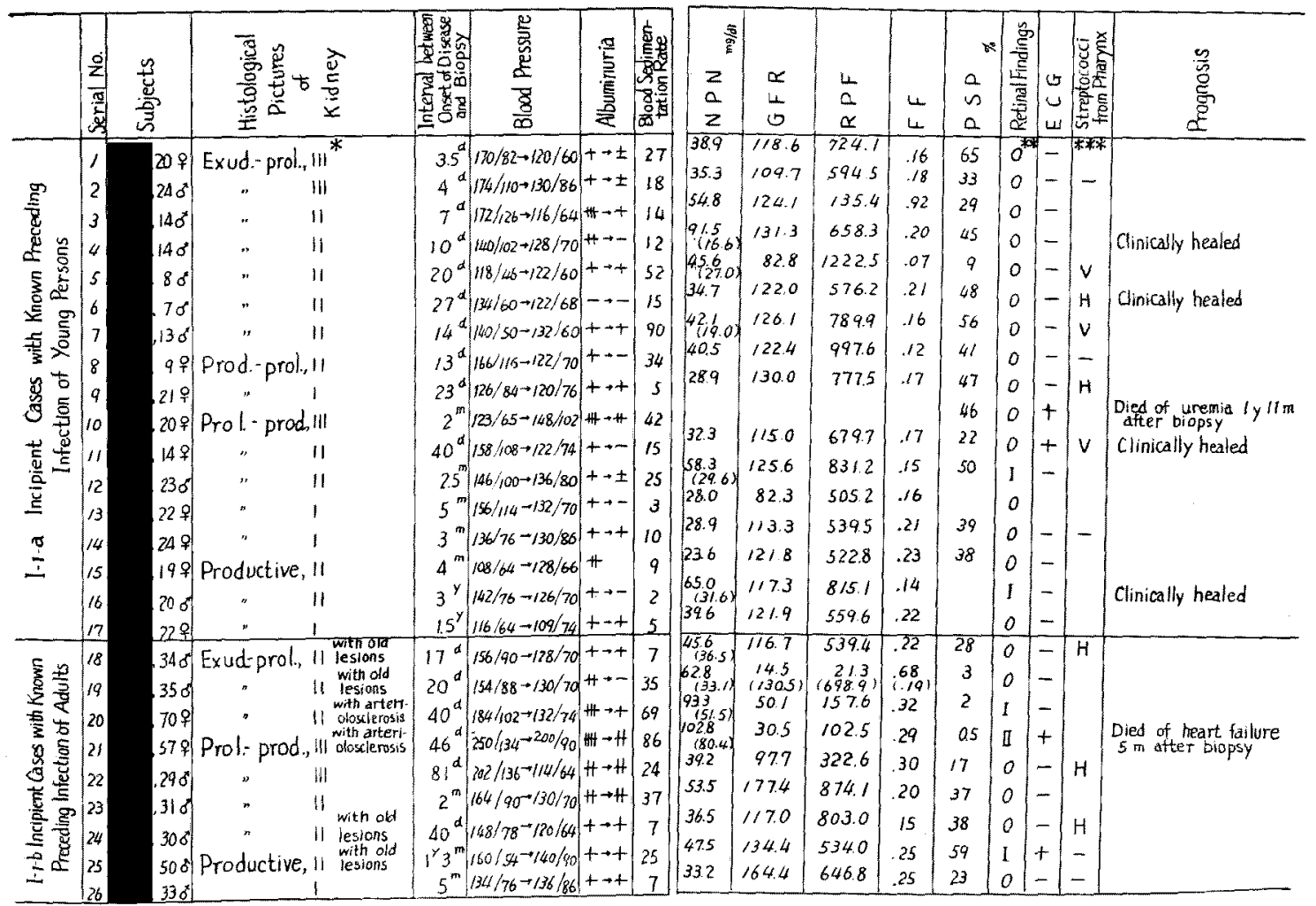

Exud., exudative; prol., proliferative; prod., productive.

* Grade of histological changes, ** According to Keith-Wagener's classification.

*** H, Streptococcus hemolyticus; V, Streptococcus viridans. 
生㛟をおこない得なかつた重症2 例については剖 検時の所見を記載し，諸樎查の結果のうち最初の 数字は腎生检時に最も近いものをとり，次の数字 はその媵の経過を示した。しかし血王および蛋白 の項以外については，1回のみの記載にとら゙め たものが多い，尿蛋白は1日尿について濃废が 1000mg/dl をを超すものを（州），500～1000mg/dlを

(卅), 100 500mg/dl (\#), 100mg/dl 以内を (十), 定量不能，もしくは，ある日は（一)，ある 日は（十）ということきものを（士）とした。眼 底所胃は，かりにKeith-Wagenerに徒い，心電 図については軽度以上の心筋障害の見出されるも のを市べて（十）として表現した。

これらの症例の既往歴, 臨床所見, 抢よび経過

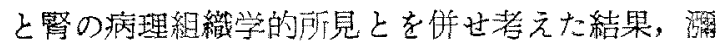
慢性系球体腎资を次のごとく分類して考察を進め
た、すなわち、

I. 初発群（症状初発のもの）

1. 先行感染明らかなもの

a. 若年群 (25才以下)

b. 壯简年群

2. 先行感染不明なもの

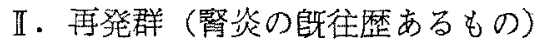

このうち再発とは初発に対する症状の再発の意味 であって，病㚆の本態からいえば再然が大部分で あううが，たとえば晹チフスにおける再発と再然 のごとき明らかな区別を付し得ないので便宜的に 再発と称した，以後もその意味において再発の辡 を用いる。

\section{I。性および年令}

上逝の分類にしたがつて年令，性を表示すると 第 2 表に示すと扮りである。総数53名中25才以下

Table 1 continued

\begin{tabular}{|c|c|c|c|c|c|c|c|c|}
\hline & $\mid \frac{3}{2}$ & 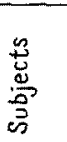 & 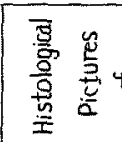 & 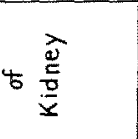 & 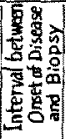 & 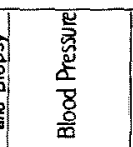 & 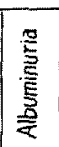 & 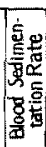 \\
\hline \multirow{14}{*}{ 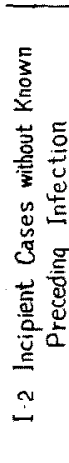 } & 27 & \multicolumn{3}{|c|}{120 Prol-prod.1 } & $3^{m}$ & $40 / 60+/ 30 / 70$ & $H \cdot H$ & 27 \\
\hline & 28 & 189 & $n$ & 1 & $1 m$ & $154 / 60 \rightarrow / 25 / 25$ &. \pm \pm & 3 \\
\hline & 29 & 149 & Productive, & & $40^{d}$ & $/ 78 / 10-154 / 100$ & H+m & 110 \\
\hline & 30 & 509 & $n$ & N & $5^{y}$ & $20 / 160-154 / 88$ & $H \rightarrow+$ & 95 \\
\hline & 31 & 335 & - & & $10^{\circ}$ & $1 / 60 / 80+158 / 66$ & $H \rightarrow H$ & 17 \\
\hline & 32 & 210 & • & $N^{\text {wit }}$ & $1^{Y} q^{\prime \prime}$ & $200 / / 24+156 / 18$ & \#-\# & 95 \\
\hline & 33 & 219 & $n$ & N & $1^{y}$ & $\mid 186 / 92 \rightarrow / 94 / 90$ & $H \rightarrow H$ & 25 \\
\hline & 34 & 186 & $"$ & III & $8^{m}$ & $140 / 60-130 / 80$ & +++ & 13 \\
\hline & 35 & 198 & $"$ & 11 & $8^{m}$ & $12 / 68+120 / 75$ & $H++$ & 16 \\
\hline & 36 & 180 & n & \| & $1^{y} 7^{-1}$ & $144 / 887 / 36 / 86$ & $H * H$ & 8 \\
\hline & 37 & 180 & - & & $8 m$ & $150 / 60 \rightarrow / 48 / 65$ & ++ \pm & 1 \\
\hline & 38 & 255 & • & 1 & $5^{m}$ & $134 / 74-138 / 80$ & $H \rightarrow$ & 20 \\
\hline & 38 & 159 & - & 1 & $?$ & $|148 / 62+146 / 80|$ & $+\rightarrow+$ & 19 \\
\hline & 40 & 168 & + & 1 & $1^{y} ?$ & $140 / 68-134 / 70$ & $+t$ & 7 \\
\hline \multirow{12}{*}{ 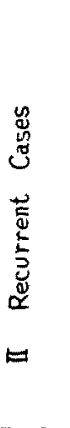 } & 41 & 180 & Prol-Prod, & & $13^{y}$ & $160 / 8 u+124180$ & $\pm \rightarrow-$ & 17 \\
\hline & 42 & 119 & " & 1 & $4^{y}$ & $96 / 50^{-1 / 12 / 58}$ & $++\infty$ & 64 \\
\hline & 43 & 288 & Productive, & & $10^{y}$ & $1 / 66 / 100+1 / 2 / 76$ & $H \rightarrow+$ & 19 \\
\hline & 44 & $46^{\circ}$ & . & IV & $7^{\gamma}$ & $180 / 120^{-}+172 / 100$ & 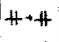 & 90 \\
\hline & 45 & 529 & & IV arteriosstensia & $22^{y}$ & $152 / 96+150 / 90$ & $t \rightarrow+$ & 35 \\
\hline & 46 & 376 & & IV with ofd & $3.5^{y}$ & $180 / 100-128 / 88$ & $H \rightarrow+4$ & 33 \\
\hline & 47 & 336 & • & III with & $17^{r}$ & $120 / 64+1 / 4 / 70$ & $+\rightarrow \pm$ & 75 \\
\hline & 48 & 216 & - & $\begin{array}{c}\text { With } \\
\text { lest }\end{array}$ & $15^{\gamma}$ & $142 / 70+120 / 60$ & $H \rightarrow H$ & 2 \\
\hline & 49 & 189 & & $\begin{array}{l}\text { With ofd } \\
\text { lesions }\end{array}$ & $45^{y}$ & $128 / 88^{\rightarrow} 110 / 76$ & $\# \rightarrow+$ & 7 \\
\hline & 50 & 419 & & if & $21^{y}$ & $/ 88 / 102^{2}+142 / 82$ & $+\cdots+$ & 11 \\
\hline & $5 t$ & 23 ? & • & & $11^{y}$ & $110 / 75+1 / 0 / 62$ & \pm- & \\
\hline & $\begin{array}{l}52 \\
53\end{array}$ & 240 & $"$ & 1 & $\begin{array}{c}11^{y} \\
8^{y}\end{array}$ & $13590^{\circ}+32 / 40$ & $\begin{array}{l}t \rightarrow+ \\
t \rightarrow t\end{array}$ & 3 \\
\hline
\end{tabular}

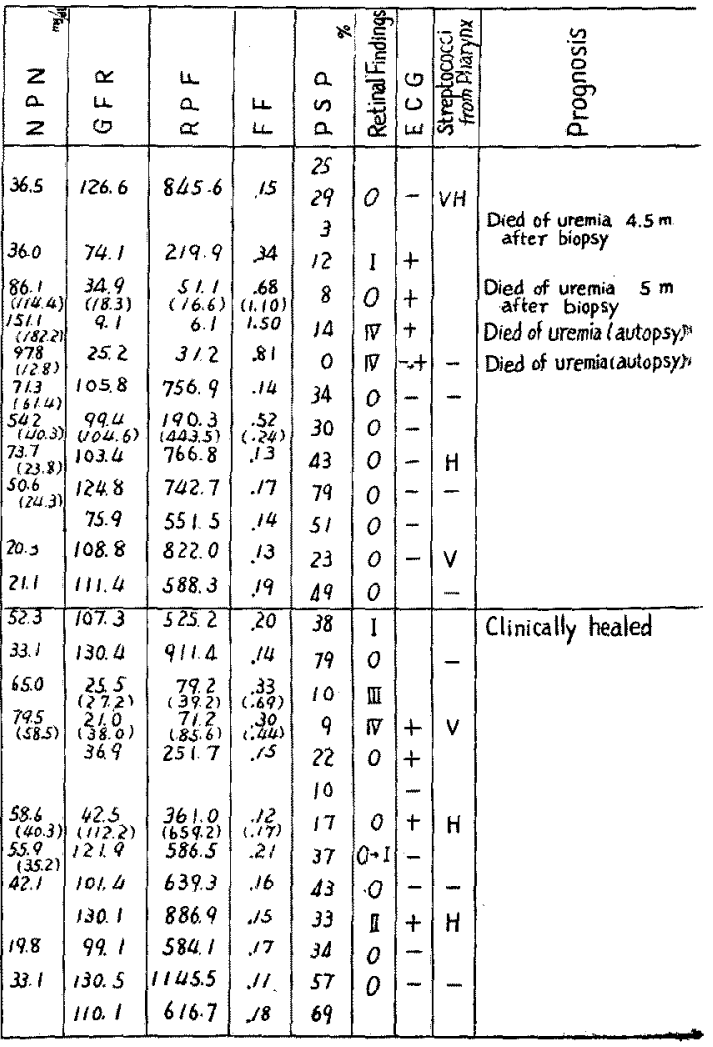


Table 2. Age and Sex

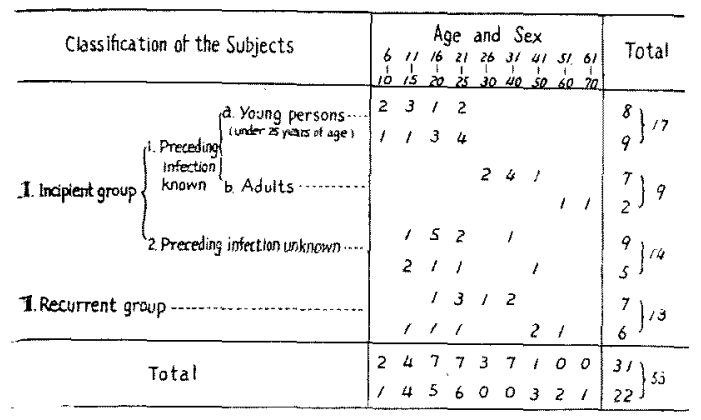

Numbers in upper rows, male; those in :under rows, female.

は36名，68\%あるが，これを先行感染ある症状初 発例, すなわ方 $(I-1-a)+(I-1-b)$ 群に 限れば26名中17名，65\%であり，再発群（II）で は13名中 7名，54\%であつて車者間に大差なく，

(I－2）群すなわ先行感染不明にして初発の 群では最も高く，14名中12名86\%を占めていた。 小睍の患者は内科においては少ないから実態とし てはさらに若年者が多いはずであるが，いずれに しても若年者に多かつたことは一般のとおりであ

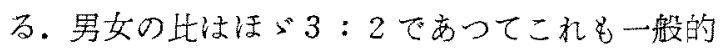
でるる

\section{II. 先行感染之発病時の症状}

先行感染の有無および種類, 照染から泟状発現 主での日数, 初発または再発時の主症状を表示す ると第 3 表に示すごとくである。このうち発症時 主症状としては, 浮腫のないものではなるべく主

Table 3. Preceding Infections and Cardinal Symptoms at the Onset

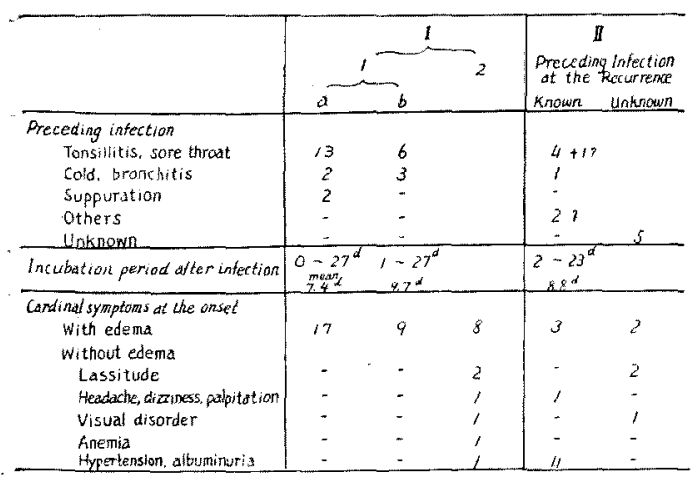

たる自覚症をとつた。本表から明らかなように， 初発群の先行感染の大部分は気道ことに上気道の 炎症であり，再発群でも再登の動機となつたと推 定できるものでは気道の炎症が多い。感染から発 痟までの日数は，ぼの群でも1，2 日ないし 3 ， 4 週で平均 7 〜10日であつた。発症時主症状につ いては，先行感染明らかなもの〉全例が浮腫をも つて始まつているに効し, 先行感染不眻, 再笔 群では浮腫以外の自覚症状をもつて受診したもの が半数ぐらいある。

\section{III. 腎の病理組織学的所見}

腎の組織所見を見ると，䠛床的には同じく急性 期あるいは慢性期の腎炎であると思う場合にも， その組織学的变化は質的, 量的に多種多様であつ て，單に急性，亞急性，亞慢性，慢性系球体督炎と いうように分類するのみにては多形的でありすぎ て理解が困難である。著者らは，筒炎が初発なり や否や, 先行感染の有然, 年命を惹虑に入れて前 記のごとく 4 群に分類するとき, 腎病变もまた比

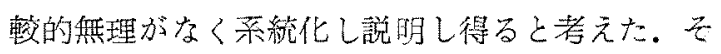
のうちで初発の先行感染の認められる若年群は発 病の様式, 経過が明膫であつて, 組織学的にも臨 東的にも理解しやすい一連の組織像を呈すること から，著者らはこの群の系球体腎炎を最も純粹な 本症の基本型とみなした。他の群の変化は，お〉 むねこれに潐拪して説明することができる。これ らの組織像についての詳細は別紙に報告する予定 であるからこっではその概略をのべる。

1. 先行感染明らかな初発若年群の組織像

組織学的所見の特徵上加ら本群の糸球体腎炎を 急性期, 亞急性期, 慢性期の三つに分け, 念性期 をさらに前期および後期に分けることができる。 杀球体の変化が主であるから，まずその大略の特 徵をのへる。

急性期前期： メサンギウ二細胞㧍よび一部内 皮ならびに上皮細胞の增殖，打よび白血球，特に 好中球の出現に由来する富榜吕㟧り，メサンギウ ムは浮腫状となる。このために毛細管腔は狭くな つて，いる叻る虚血の状態となり，䒺球体は腫大 
Fig. 1. Case No. 2. Former phase of acute stage. Exudative-proliferative glomerulonephritis, Grade III.

Glomerulus is markedly enlarged. Mesangial cells are swollen and proliferated. Moderate number of leukocytes are present in the lumina of capillaries and edematously swollen mesangial tissue.

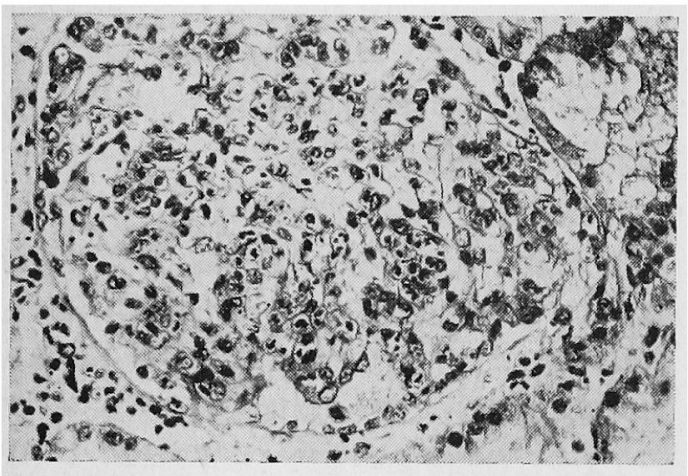

する。この所見, 特に自血球の存在加ら,この变

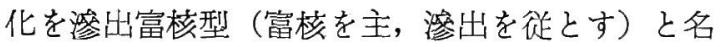
づけた。第 1 表中では症例No. 1 〜 がこれに相 当し，発病より腎生検までの日数は3.5日〜27日 であつた。時日の経過と〉もに毛細血管の再疏通 がおこる。これは割合に早く扢こるもので1週以 後の症例では，膨大したメサンギウムの外側から の压迫による管腔の狭小化はあるが，細胞成分に よる内腔の閉塞はきわめて軽度になる (第 1 図).

急性期後期：白血球は消失し，メサンギウム の浮腫も軽減し, 滲出性変化は軽度となり, 一力 メサンギウム線維の增殖が始まる。しかし組織像 を支配するものは依然としてメサンギウムの富核 である。この所見からこの時期の像を増殖富核型 と名うけた、第 1 表中では No. $8 ， 9$ がこれに ぞくし発病後13日，23日目である。このほかに症 例No.4の第 2 回目生檢（発病後34日目）の像が これに入る(第2 2 図).

亞急性期：メサンギウム線維の形成が進み, 基底膜の肥厚が種々の程度にみられる。富核は前 の時期よりは減少しているがなおあり, 核の大小 不同もまだ楒められる、組織学的にはこれを富核 増殖型と名づけた。症例No.10〜14がこれにぞく
Fig. 2. Case No. 8. Latter phase of acute stage. Productive-proliferative glomerulonephritis, Grade II.

Mesangial cells are swollen and proliferated as in the former phase, while the leukocytes have disappeared and the lumina of capillaries are already nearly free from obliterative changes. Mesangial fibers begin to increase.

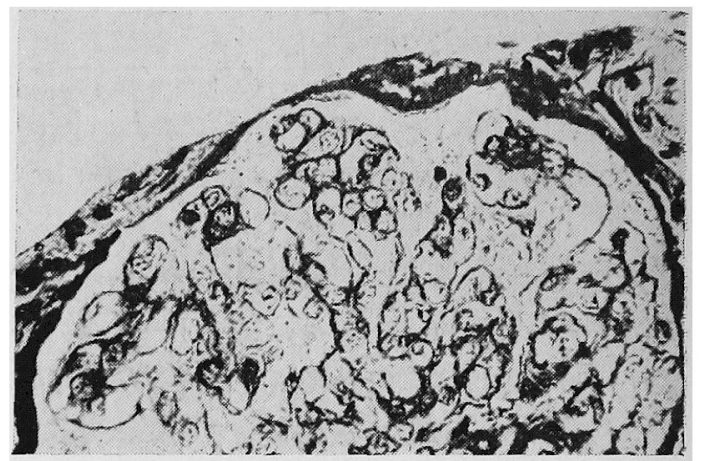

Fig. 3. Case No. 2. The third biopsy. Subacute stage. Proliferativ productive glomerulonephritis, Grade I.

Mesangium is slightly widened in the stalklike pattern. Mesangial cells became fairly small and are reduced in number. Mesangial fibers are increased in number and density.

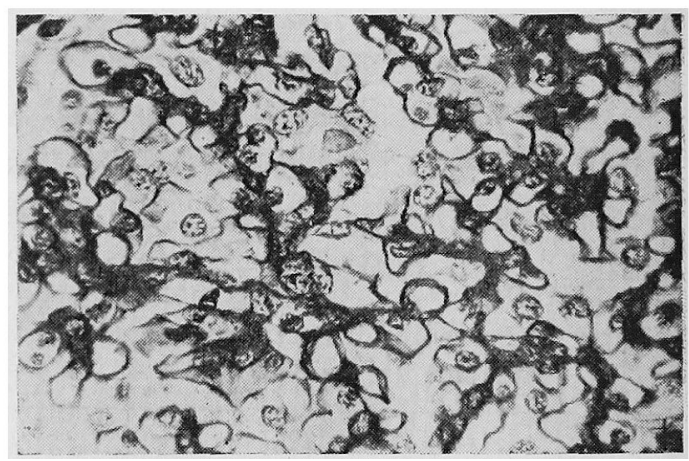

し，発病後40日ないし 5 力月である(第 3 図).

慢性期：富核は著明に消退してメメサンギウ 么線維の増殖が主役を演ずる，基底膜は病変のい ちじるしい例では，ますます肥厚するが，軽症の ものではほとんど正常に近い。この所見を組織学 的には增殖型とい〉得る. 症例No.15〜17がこれ にぞくし, 発病後 4 カ月ないし 3 年であつた（第 4 図). 
Fig. 4. Case No. 15. Chronic stage. Productive glomerulonephritis, Grade II.

Mesangial fibers are more and more produced and the lobules of glomeruli are adherent to each other. Proliferation of mesangial cells is not prominent.

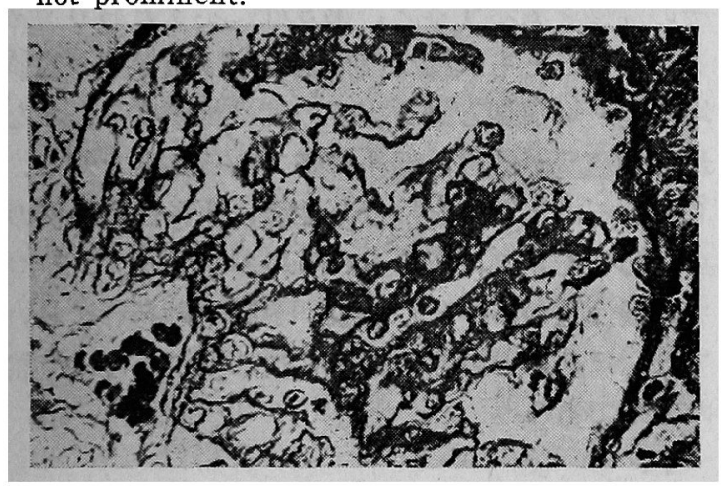

Table 4. Histo-pathological Classification of Incipient Glomerulonephritis of Young Persons

\begin{tabular}{|c|c|c|c|c|c|}
\hline \multirow{2}{*}{$\begin{aligned} & \text { Histo-pathological } \\
= & \text { Classification }\end{aligned}$} & \multicolumn{3}{|c|}{ Histological Changes in Glomeruli } & \multirow{2}{*}{$\begin{array}{l}\text { Time Length } \\
\text { after the Onset } \\
\text { of the Disease }\end{array}$} & \multirow[b]{2}{*}{ Clinical Stage } \\
\hline & Levcocytes & $\begin{array}{l}\text { Mesangial } \\
\text { Cells }\end{array}$ & $\begin{array}{l}\text { Mesangial } \\
\text { Fibers }\end{array}$ & & \\
\hline $\begin{array}{c}1 . \\
\text { Exudative proliferative } \\
\text { form }\end{array}$ & $\begin{array}{l}\text { Ht } \\
! \\
+\end{array}$ & $\begin{array}{c}\text { Hit } \\
1 \\
1+1\end{array}$ & $\begin{array}{l}\bar{b} \\
\pm\end{array}$ & $35-27^{d}$ & \multirow{2}{*}{$\begin{array}{ll}\text { Former } & \\
& \text { Acute } \\
& \text { stage } \\
\text { Latter } & \end{array}$} \\
\hline $\begin{array}{l}\text { Productive-proliferative } \\
\text { form }\end{array}$ & - & H & + & $13-34^{d}$ & \\
\hline $\begin{array}{l}\text { Proliferative-productive } \\
\text { form }\end{array}$ & - & $H$ & $H$ & $40^{d}-5^{m}$ & Subacute stage \\
\hline $\begin{array}{l}4 . \\
\text { Productive form }\end{array}$ & - & $t \sim H$ & H & $4^{m}-3^{y}$ & Chronic stage \\
\hline
\end{tabular}

この群の組織学的特徴と臨床的経過との関係を 表示すると第 4 表のとおりである.

以上の各型の変化それぞれに軽重があり, 糸球 体の変化を主眼として病変の重いものを止度, 中 等度のものを II 度，軽度のものを I 度とした。た たし慢性期 (増殖型)においては軽重の差がいち じるしいので 4 度に分けた。本群の亜急性期掞よ び慢性期の症例中病变高度のものは症例 No. 10 の1例だけであつた。

系球体の上述の変化に対して, 系球体以外の部 分, すなわち, Bowman 氏䘫, 尿細管, 皮質間 質の変化は大略系球体の病変に質的にも量的にも 平行するといつてよく，血管の変化はほとんど問
題とならない。

2. 先行感染明らかな初発壮高年群の組織像

No. 18〜26の 9 例が本群にぞくする.この群の 組織像は前群に比し一般に複雑であつて, 皮質間 質, 尿細管, 血管の变化も種々の程度に加わつて くる.しかしょく観察すると, 古い糸球体腎炎の 上に重なつた新しい，または，比較的新しい腎炎， が認められる場合（症例 No. 18，19，24，25） と,細動脈硬化が下地にあると考えられる場合(症 例 No.20，21）とがある.この古い腎炎と細動脈 硬化とから，ひとまず目をそらして，新しい変化 のみに着目するとき, その变化山若年初発群々同 様な型に分けることができ，その型と発症からの 経過日数との関係は前群と同様に成立つ. 第 1 表 の組織所見は新しい变化を中心として分類したも のである。これから考えると, 本群には眞の初発 腎炎もあるが（症例 No. 22，23，26），既往のし かし病覚がなくて経過した腎炎の上に抗こつた新 しい腎炎，換言すれば実質的には再発群に入れる へきものが少なくなく，さらに高年群なるゆえに 細動㟲硬化を伴なうものも多くなると思われる。

3. 先行感染不明な初発群および再発群の組織 像

先行感染不明な初発群は14名, 再発群は13名あ る.この両群の組織変化は，表に見るように，基 本的にはこれまでの群と同様な型に分類できると 思われるが, 実際嵪度, 陳旧のものが多く, い ずれにも急性期にぞくする組織像すなわち滲出富 核型，増殖富核型を呈するものがなく，ともに大 部分の例は慢性の増殖型であうて，しばしば硝子 化した糸球体を有し，亜急性像である富核増殖型 も，おのおのに2 例あるにすぎない。糸球体のみ ならず，尿細管や皮質間質の病変も著明なものが 多くなり，慢性の続発性萎縮腎に至る像が見ら れ，また血管変化も加わつて来，ことに高年者の 病変は高度である。また新旧病変の混在の認めら れる例 (No. 32，37，および No. 45，46４8， 49）がある。このさい新旧病変の混在と解した場 合は，糸球体によつて慢性期あるいは亜急性期の 
病变を示したり（No. 48，49）あるいはすべて の糸球体がいちじるしく慢性期病亲を呈しながら も，その一部に明らかに，上り古い病変たと光ば 完全に硝子化，繀小し，周囲加らの吸收像の認め られるいわゆる旃痕様硝子小球(No. 32，45，46)

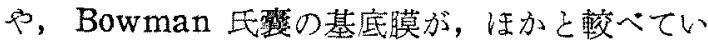
ちじるしく肥厚し，毛細血管楴係も萎縮性硬化比 陷つているような系球体（No. 37）方存在する場 合である。これは再発群においては当然だが，初 発群においては症状初発なが方実体は再発なるこ とを想定せしめるものと解した。

なお半月体については典型的なものは症洌 No. 21 （初発壮高年群，富榜増殖型 II 度十細動眽硬 化）にみられ，典型的ではないが半月体と稱すべ きものはNo.3 (初発若年群, 滲出富榜型而度), No. 30 (先行感染不明群，増殖型 $N$ 度)，No. 46扔

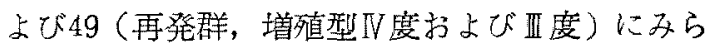

Table 5. Changes of Histological Pictures during the Course of the Disease

\begin{tabular}{|c|c|c|c|c|c|}
\hline Groups & Cases & $\begin{array}{l}\text { Exudative } \\
\text { proliferative } \\
\text { form }\end{array}$ & $\begin{array}{l}\text { Histologica } \\
\text { Productive- } \\
\text { prolferative } \\
\text { form }\end{array}$ & $\begin{array}{l}\text { Pictures } \\
\text { Proliferative } \\
\text { productive } \\
\text { form }\end{array}$ & $\begin{array}{l}\text { Productive } \\
\text { form }\end{array}$ \\
\hline $\int_{1}^{1}\left\{\int_{b}^{a}\right.$ & 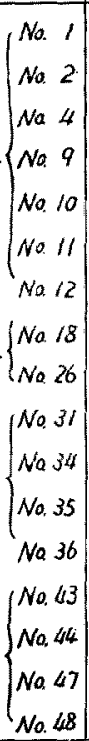 & $\begin{array}{l}11 \stackrel{11 d}{-} \cdot 11 \\
11- \\
11-34 d\end{array}$ & $\begin{array}{l}49 d \\
11\end{array}$ & 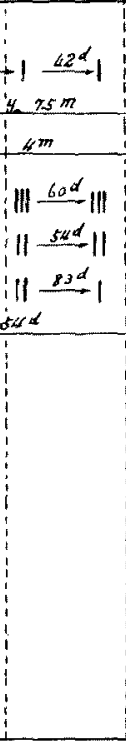 & 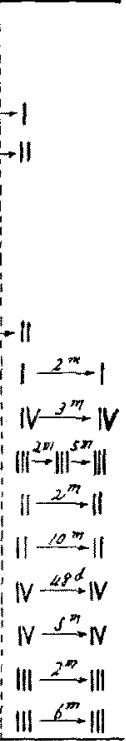 \\
\hline
\end{tabular}

Numbers on the arrows are the intervals between biopsies. d, days; $m$, months; y, years.
れた。ちれらの例に共通して，尿蛋白濃度は高か つた.

\section{IV. 組織像の推移}

2 回以上腎組織像を検索し得た17例について， その推移を涪示すると，第 5 表に示すとおりであ る. 軽快とともに渗出富校型 $\rightarrow$ 増殖富核型 $\rightarrow$ 富核 増殖型 $\rightarrow$ 増殖型と勤き病変の度は軽減する。すな わち增殖型が修復，軽快の姿であることを知る。 しかしそのような軽快は急性型，西急性型の例の 多い初発若年群に認められるのが大部分であつ て，慢性型の多い先行感染不明群や再発群におい ては，ほとえど動きの認められなかつたのは当然 の結果であろう。

\section{V. 予後}

少なくも2为月の観察において，常に血圧正 常，尿蛋白陰性で腎機能正常，自覚症なきものを 臨床的治療とみなすとき，それに暞当する例は初 発若年群に抢いて 4 例 (No. 4，6，11，16)，再 発群において1例あるのみである（前者の群中な お $1 ， 2$ の治瘺例を加え得るか子も思わ礼るが， 追求期間が不充分なので除外した．前者の群にを くする治癔例の組織学的変化は各型にわたるが高 度のものはなく，再発群の 1 例は13年前の古い腎 炎の痕跡の上に招きたI度の再発であつた。すな わち軽度の急性病変にのみ臨床的治瘁を期待し得 るもの存ることを知る。

一方，死亡例についてみると，最も著明な事実 は6 例中 4 例（No. 29，31，32，33）方先行感染 不明初発群にそくし，しかも 4 例とも比較的短期 間の経過（発病後やく 6 力月， 1 年 3 力月， 1 年 9 力月，1年）をもつて尿䓯症により死亡し，年 令は比較的若く，組織像は高度の堌殖型（萎縮 瞥) を呈したことであつた。これに対し再発群に はふしぎにも 1 例の死亡もなく，中には典型的萎 縮鋳の組織像と浮腫を呈しながら，すでに5年に わたり生存しつづけている例专ある.他の死亡 2 例中 1 例は初発壮高年群の57才の例 (No.21) で あり、この死因の主たるものは心不全であつた。 他の 1 例は初発若年群中にあり（No. 10), 本例の 
病変は高度で, 全経過 2 年 1 カ月で尿毒症により 死ししている．なお死亡例はすへて尿蛋白著明で あり，大部分血圧も高く，赤沈も促進している。

VI. 腎機能その他の臨床所見

腎クリアランス值については初発若年群に拀い て急性期および亞急性期に G F Rが多少低下して いる例があつたが，いちしるしい障害のある例は みられず，慢性期にぞくする4例はすべて正常值 を示した。これに対して初発壯高年群では急性 期，亞急性期においても腎クリアランス不良の例 がありそのような例の多くには既経の腎炎の跡

(No. 19) や, 細動脈硬化 (No. 20, 21) が認め られた。先行感染不明群および再発群について は, 病変の重いものに扔いて腎機能はいちじるし く不良であった。

PSPについては全体としてみるとき，GFR およぴRPFと同様な傾向を示すが，初登若年群 の急性期, 亞急性期の症例においても治療初期に は低值を示すものがある。

NPNについてはいずれの群，いずれの期にお いても治療の初期には正常檤より高い例がみられ るが, ことに先行感染不明群, 再発群の病变高度 の例および初発壯高年群中細動脈硬化の下地があ る例に，高值を示すものが多いことは当然であろ う.

收縮期血压は若年初登群で怯急性期最も高く, 亞急性期がこれに次ぎ, 慢性期ではほとんど正常 化するが、な放少し高目の例がみられる。この群に 比すれば壯高年群は一般に血压や〉高く, 先行感 染不明群および再発群中の腎病雜の高度のもので は最も高い，治尞によつて血任の改善がいちじる しくないものは当然病変の高度なるものに多い。

赤沈についても汪ぶ同樣な傾向代認められ，急 性期に高く，慢性期に向つて低くなり，また怪快 に伴なつて低下するが，病零高度のもの，予後不 良の老のにおいて促進例がみられる. 赤沈の促進 に関する因子は，感染，貧血，血濌蛋白があり， 簡單ではないが，一般に筒炎にさいし，赤沈の高 低はいずれの期，群にあつても疾病の重さをある
程度示すようである。

眼底㧍よび心電図所見については，初発若年群 の変化が最も軽度, 少数であり, 初発壯高年群こ れに次ぎ，先行感染不明群および再発群において 最も著明かつ多数である。

VII. -Antistreptolysin-O 洒の推移扝よび咽頭 培養

第 1 表所載の症例中A S LO を測定し得た37例 について，をの推移を图示すると第 5 図を得る。 図の橫軸は日数を対数的に表現したものであり，

Fig. 5. Antistreptolysin-O Titer and the Oldness of the Disease

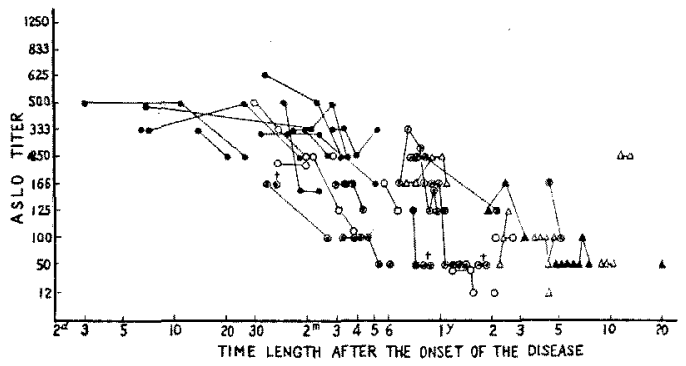

- Group I-1-a

Group I-1-b

(-) Group I-2

$\triangle$ Recurrence, preceding infection known

A Recurrence, preceding infection unknown

+ Fatal case

Group II

先行感染明らかなものでは，感染の初日から起算 し，先行感染の不明な例々再発例では最初の症状 発現のときから計算した。しかるときは四から明 らかなように興味ある所見を示す。すなわち先行 㤫染ある初発例についてみるに，AＳＬO洒は病 初上り高く，各群中最高古占好て抢り，3力丹前 後加低下しはじめ，4〜6力月ごるに正常䈇明 に低下する。これに対し再発群は低值を示すもの が最も多いが，てのうちで軓発時先行感染の認わ られる例では高値を示すものがある。先行感染不 明群のA S LO価は一般にこれらの中間にあり， 本群中に見出される死亡例のASLO洒は，各時 点にあたる症例中では，そ礼たれ最低位を示し 
た。な㧍先行感染の明らかな初発例の急性期には 8 例について測定してあるが，そのいずれも 333 單位以上の高いA S LOO洒を示した。

咽頭からの培養をおこなつたものは26例あり， 種アの菌が検出されているが，そのうち Streptococcus hemolyticus と viridans のみをと上 げると hemolyticus のみを检出したもの8例， viridans のみを检出したもの5例，雨者を検出 したもの1例であつた。これらは各群各期に散乱 しているが，hemolyticus 証明した9例中 5 例は166單位以上のASLO価を示した。

\section{考案}

著者らは做慢性系球体腎炎を，症状初発にして 先行感染の見出される若年群抢よび壮高年群, 先 行感染不明ではあるが症状初発の群, 再発群の 4 群に分け，各群につき原則的には組織学的, 臨床 的に急性期, 亞急性期, 慢性期を區別し得るもの とし(たぶし，たとえば再発例の亞急性期とは新 しい腎炎の変化が亞急性期に属する意味である， このうち先行暿染が明らかであつて初発の若年例 に見られる組織像が本症の最も単純な基本型であ ると考えた。この基本型に拀いてはきわめて初期 には，系球体に白血球の出钼を伴なうこころの渗 出々富核の機転があり，まもなく白血球は消失 し, 修復機序が始まり, 一方富核の状態ま徐々に 消退するという，炎症加ら修復への一連の過程と して容易に受计々られる像が琹められる。しかし

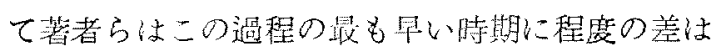
あれ白血球が必才゙見出されることを重視し、これ を組織学的には渗出澢核型，時期的には急性前期 と名づけた。徉来の剖検材料を基礎とする病望学 においては初期の白血球出現については, Gräff ${ }^{14)}$ はこれを重視したがその後は必ずしも重要視され ておらずたとえば Bel115) は acute proliferative glomerulonephritis $\sigma^{2} / 3$ 以上の例に種々な る程度の多形核白血球がみられるとい, Bell のいう exudative type は葡萄菌感染の特別な場 合をさして扔るようであるし，Fishberg16) は単 に proliferationとともに多形核白血球の集積
がみられると述べ，Anderson の著 Pathology (1957) においては白血球はときに多数とし， Kaufmann-Staemmler の著（1957）には白血 球は䈏核の一部をなし，血管内に認められると記 載されて少り，矢島 ${ }^{17)}$ は，白血球浸潤は急性型の 一部で認められるのみで系球体炎の一次的必発的 変化とはみなしがたいとしている。しかし我々の 発病 3.5日〜27日の7例の急性例に扔いてはすべ て白血球が認められ，13日，23日の2例において

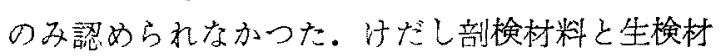
料との違いによるであろう。我々は早期の白血球 出現は必発と考えている。この点において exudative form $\varepsilon$ proliferative form $と は$ 時 期的な違いを示すにすぎいとする Grishman and Churg's の報告々軌を一にするものであ 万.

白血球消失のころがらメサンギウムの浮腫，メ サンギウム細胞の膨化は消退し，一方メサンギウ 厶内の線維増殖が始まる。著者らのいう増殖富核 型であり，急性後期であるるづいて富榜は徐々 に減少し, 線維增殖は徐々に増加し, 修復が進 み，亞急性期加慢性期人，著者らのいう富核堌 殖型加ら增殖型へと移行してゆく. 系球体のこれ らの変化に対して㽷細管，皮質間質，Bowman

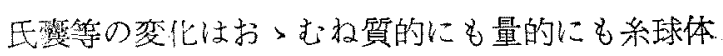
のそれに比例している。すなわちこれらの病変型 は時間的順に経過しゆくものであり，これが糸球 体腎炎の基本の形であると考えられる。もし病变 が重篤であれば急性期の虚血, 炎症の激しい時期 において，あるいは修復の過程における杀球体の 䒜廃によつて，腎不全がおこり不幸の転帰をとり 得るであろうし(症例 No.10)，もし軽症であれ ば糸球体蹄係にわずかの線維化を残すのみとなつ て (症例 No. 4 第 3 回生榆像), 治㦄像を示すこ とになるであるう。矢息181は急性糸球体腎炎を繁 殖一変質性, 増殖性, 渗出一繁殖一変質性, 変質 一增殖性の膜内型㧍よび膜外型を示す変質性の 5 型に分け，同じく急性源慢性糸球体腎炎とはいつ てもその像にはかなりの相違があると述べている 
が，生検材料とは違つて，剖検された重症例の組 織像が複雜多彩なことは容易に想像される。

この基本型の上に立つて観察すると，他の群の 蜸焱も多くは説明し得ることは既述した。なお亞 急性腎炎りさいに多く見られるという半月体につ いてはその存在が重視されて膜内型，膜外型の區 别がなされておる場合もあるが，著者らの症例に おいては，急性期に 1 例，亞急性期に 1 例，あま り古くない再発群に 3 例見られ，いずれも病変は 高度であり，蛋白尿著明であつたことから考える に，半月体は蛋白尿著明で炎症が激しいときに生 ずるものであって，必すしも一次的な意義を附し 得ないのではあるまいかと思われる。

観察を総括するに最初に分類した 4 群は次のよ うに整理し直される。すなわち，( $\alpha)$ 多くは若 年に見出される初発の基本型腎炎，その多くは先 行感染が認められ浮腫をもつて始まる。完治山あ まり多くないが（たぶし著者らの小罗の少ない材 料に打いて）当面の予後は良好（（侢発腎

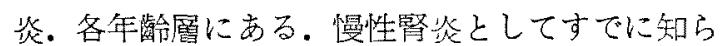

Table 6. Details of the Cases of Group I-2

\begin{tabular}{|c|c|c|c|c|c|c|c|}
\hline Case & Histalogical Findings & $\begin{array}{c}\text { Outcone } \\
\text { (Duration) }\end{array}$ & Onset & $\begin{array}{r}\text { Ede } \\
\text { Aft the Onsed }\end{array}$ & Fensidery & ASLO & 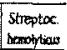 \\
\hline Na.27. $12 d$ & Prolprod 1 & & Abrupt & + & - & & \\
\hline 28,189 & $\cdot 1$ & & Insidious & + & - & $100 \rightarrow 50$ & + \\
\hline 29.149 & Prod. IV & 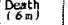 & Abrupt? & + & - & 166 & \\
\hline 30,509 & . N & & insidious & + & $\stackrel{\text { Alqurst }}{+}$ & $166 \rightarrow 100$ & \\
\hline $31.33 \mathrm{o}$ & $\sim N$ & $\begin{array}{l}\text { Desthy } \\
\text { Desty } \\
\text { iny }\end{array}$ & Insidious & + & - & $125-50$ & \\
\hline 32.210 & * N with oul lesiors & 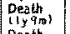 & Abrupt & 精 & $\stackrel{\text { Almost }}{+}$ & $50-50$ & \\
\hline 33.219 & $\cdot N$ & $\begin{array}{l}\text { Deatk } \\
\text { iły }\end{array}$ & Insidious & $-\infty$ & + & & - \\
\hline 34.186 & 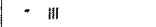 & & Insidious & \pm & - & $166 \rightarrow 50$ & - \\
\hline $35.190^{\circ}$ & $=4$ & & Insidiatus & - & - & $250 \rightarrow+25$ & \\
\hline 36,180 & - II & & Abrupt & + & - & & + \\
\hline 37. 18 of & - If whoth lessions & & Insidious & - & - & $333-125$ & - \\
\hline 38.250 & $\Rightarrow 1$ & & Insidlaus & - & - & $106-100$ & - \\
\hline 34.159 & $\cdot 1$ & & Insidious & - & - & 50 & - \\
\hline 40,1606 & .1 & & Insidiaus & - & - & $66-725$ & - \\
\hline
\end{tabular}

れている場合と，初発の仮面を被る場合とがあ る。媵者忙壯高年群に多い. $(\gamma)$ 先行感染不明 の初発群。年令的には若年者が多い。この群には 最も問題があるので別に表示すると第 6 表のごと くである。特異な事実は死亡例の多いこと〉，発 病が徐々潜行的な例の多いことである，浮腫のな い例も少なからず，西つてもいつ発生したか定か でないものが少なくない。また浮腫例の組織変化
をみると富核増殖型（亞急性期）の2例では軽 度であつたが，增殖型（慢性期）の例では1例 (No. 36) 徐き最高度 (IV度) の病変を示してい た。この点加ら考えると, 徐々に発病する場合に は浮腫を来たすことは少なく，もし徐々の発病な がら浮腫がある場合には，病変は高度であると推 察される，死亡例は 4 例あり，すべての群の中で 最も多い，全例とも最高度の增殖型病变を呈し, 腎機能はいちじるしく不良であり，一路悪化する か，臨床的にはいつたん改善されても，まもなく 破綻を来たして死の転帰をとつたものであり，全 経過は 6 力月〜 1 年 9 力月であつた。一部の例

(No.29，33) は Volhard, Fahr らのいう亞急 性腎炎に当るべく，他の 2 例多経過は少し長いが 同じ範疇に入れ得るものかと思われる。また本群 の例ではないが，先行感染の明らかな初発の若年 例 No.10が亞急性期に観察された後, 全経過や く2年で死亡しているが，二の例も本群の死亡例 と形式を同じくするものではなかるうか．かく考 えるとこれらの死亡例は初回の attack が激しい 病変を規定し，組織変化は修復に向つたが，つい に婜不全を扢こさがるを得なかつたものと解され る。このような形の腎炎が慢性のいわゆる続発性 萎縮腎として存続する可能性は考えにくいから，

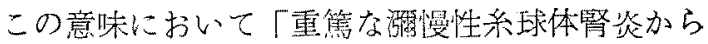
は続発性萎縮㹂の発来ということは考えられな い」とする岡林199の意兌に蕒省を表する。たぶし 必ず初回の attack のみが重要であるいうには 多少の保留を要する。なんとなれば No. 320死 亡例に括いて，再発としても考えられる組織像が 認められているからである。

本群の発病がいかなる機序によるかを明らかに することはむすかしい，多くの場合，現われたと おりに初発の婜炎と考えたいが，ときには再発と 考えられる例名ある。徐乃の発病に対しては, たとえば感染とアレルギ一の特殊なあり亦仮 定し，死亡例についてはAＬO価が前記のご とく各時点に扔いては最も低位にあつたことか ら，陰性アネルギーもしく汢体内抗原過剩の状態 
などを仮定することができるが，その検討は今後 にまた襍ばらない。

著者らの分析は $\mathrm{E} 11 \mathrm{sis}^{20)}$ のそれと若干の共通点 を有するのでこれと对比してみる必要がある。

EIlis は1942年多数の材料の臨床病理学的観察か ら算炎を Type 1 と Type 2 に分计た. Type 1 は発病急激なるものと定義され，これに艺いす るもの一般症状著明で多くは先行感染が見出さ れ，浮腫は短期間であり，若年者に多い，その予 徣は（1）回復 $82 \% ， （ 2 ）$ 急性期における死亡 $4 \%$ ，（3）Volhard のいわゆる亞急性腎炎 4 $\%$ （4）急性症状は消失するがきわ的て慢性の 経過をとるもの10\%上述べた。（1）壮著者らの $(\alpha)$ 中の多くの部分に当り，(2) は著者経

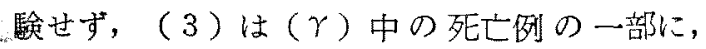
(4)は $(\alpha)$ 中の完治せ好ものよび $(\beta)$ に大 略相当するであろう. Ellis の Type 2 は発病潜 行的と規定され，先行感染の認められること少な く, 浮腫は持続的で, 治瘺ははなはだ少ない。 れにはネフローゼ在候群も含まれる．著者らの場 合ネフローゼ症候群を除外してあるので， Ellis の分類によく相当するものは梳なな゙少ないが，

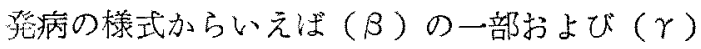
の大部がこれに当るであるう。

汧雨慢性系球体腎炎の成因に溶連菌が重要な役割 を果たしていることは定説であるが，著者らの成 續においても初発の急性期に測定し得た全例が高 いAＬＬO価を示したこと，再発時にも高まつて いる例のある事実からみる, 溶連菌感染已本症

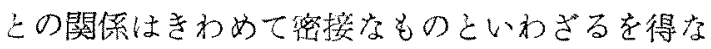
い。またASLO価が正常範围に低下するには 4 〜 6 力月以上要するし，本論文ではふれなかつ ゲが血清シアリン酸值が正常化するにも同様な期

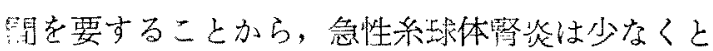
も半年間活動性であるるみて安靜加瘦をおこなう 人きものと考える。病理組織学的にも組織が落着 きをみせて富核熄殖型加ら増殖型に移行するのは 大体半年以後のことである。

以上を総括考察するに，系球体腎炎は主として
溶連菌感染に関漸して若年者におこる疾患であ り, そのときの病変は恐らく感染のあり方々素質 (アレルギーを主とするところの)のいかんによ つて，きわめて軽度のものから最も高度のものに わたる、最も軽度のものは全く subclinical に経 過して筲組織にはわずかの証拋を残すかにれが 非常に多いらしいことは成人についての腎炎以外 の篮生検像から想像される）あるいは残さないで あろうし，最も重症のものは急性期において死亡 し，中等度のものは一応の安定を得て欠損治癒の 形をとり，臨床的には腎炎は慢性化 (latent chronic)するであろう，再発，再然は感染などを動 機としておこり，腎炎を悪化させる理由となる。 しかし病変の重さを支配するのは初回の侵暍にあ るように思う。数力月ないし 1 年数力月の時日で 死に至る例は，急性期はもちこたえたが修復の過 程において破綻を来たしたものと解されるが，そ の背景にアレルギーの特殊な場合を想像し得るか 当しれい。

このように考えて来ると，本症は結核の初感染 の転㷌に比喛を求めることができそうである。す なわち結核初感染の大部分は若年におこり subclinical に終始し，一部は発病するが跡を残して 沿瘺し，一部は肺瘦に発展して㪕快しあるいは死 亡する。悪化は狤核においては主に再然によつて 進められる，経過を支配するものはやはり感染と アレルギーを含むところの素質の相関である、两 者の重大な相違は結核において肺機能不全は容易 におこらないが，本症では源慢性なるがゆえに， 急性期の炎症また泣久損治凂によつて容易に腎不 全が抢こり得ることにある。この比喻をもつてす れは多くは若年者に㧈こる真の初発の糸球体腎 炎は childhood typeであり，そのほかは adult type ということができよう。

\section{総 括}

溜慢性系球体腎炎の臨木像, 経過, 予後之腎病 変との関係を知る目的で，ネフローゼ症儌群を除 外した53名の本症患者について，腎生検，篎機能 検查, antistreptolysin-O 值測定, そのほかの 
諸検查をおこない最長 5 年にわたり追求観察し た.

年令, 先行感染の有無および症状初発なりや再 発なりやを考慮して，先行感染明らかな初発若年 群 (25才以下), 先行感染明らかな初発壮高年群, 先行感染不明の初登群，および再発群の四つに症 例を分けるとき，先行感染明らかな初発若年群に 見られる組織像は本症の基本型とみなされる。

この基本型流球体の病变を主として渗出富核 型, 增殖富核型, 富核堌殖型, 増殖型と称し得る 時間的順に経過する 4 型に分類し得，初期には白 血球出現の認わられるのが特愷的である。䠦床的 な時期と対比するとそれでれ急性前期，急性後 期, 亞急性期, 慢性期にほぶ相当する，尿細管，

Bowman 氏罴，皮䫓，間質などの变化は質的にも 量的にも糸球体病変にお〉む称迫往するといつて よい，血管の变化ははなはだ少ない。

汪かの群の組䢂像もおっむ坟これに準じて表現 できるが，増殖型（慢性期）が多く，病変も高度 の例が多くなり，をれに彷つて血管の变化も加わ り,ことに年長者にいちじるしく，組織像は複雑 になる，壮年以上の例では腎炎初発上みえて実質 的には再発が少なくなかつた。

先行感染の認められる例のすへでは浮腫をもつ て急激に発病しているのに，そ㣗の認められない 例ではやく半数が浮腫孛伴存い，大部分が徐々に 発病している。この場合発病徐々ながら浮腫の出 現した例の腎変化は多くは重篤であつた，再発の さいに先行する感染が認められる場合が少なくな w.

腎機能は一般的にいえば急性期に鞋度に障害さ れるが間もなく回復し，慢性期の病变高度の例で はいちじるしく障害されている。赤沈はどの时期 においても疾病の重さのかなりの目安になる。

Antistreptolysin-O 值の消長からみると，溶 連菌が本症の成因に果たす役割はきわめて大きい と思われる。またその推移から祭すると，念性腎 炎は短くとも半年間活動性であるとみなして，治 療すべきであると考えられる。このことは組織所
見からも裏づけられる。

死亡 6 例中 4 例は若年者であり，4例では先行 感染不明であつた。死因は高年の 1 例では主とし て心不全にあつたが，他の 5 例は鳌不全であり， この 5 例の全経過は半年ないし 2 年 1 力月であつ た。

以上の観察から采球体腎炇の起始已進屡を次の ように考えてみたい。すなわち本症は主として溶 連菌感染に関連して若年者におこる疾㭧であつ て、その上きの病変は最軽度から最高度まであら ゆる段階があり，最軽度のものは subclinicalに 終始し，中等度のものは急性期妾過ぎて安定し欠 損治瘾の結果として latent chronic の状態とな り，高度のもの江急性期は通過し得ても修復の過 程において破綻を来たし，最高度のものは急性期 の腎不全によつて死の転門をとるというょうに考 え得よう。再発，再然は腎炎を悪化せしめるが，

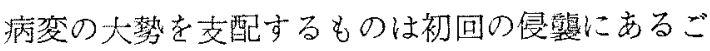
とく思われる。

(本論文の一部の要旨注第56回日本内科学会総会及 び第48回日本病理学会総会で発表した).

\section{文献}

1) Parrish, A.E., et al.: Amer. J. Med. Sci., $229: 632,1955 .-2)$ Grishman, E., et al.: Amer. J. Pathol., 33 : 993, 1957, 一 - 木) 木下廃民: 最 新医学, $11: 3023$, 昭 31 . 一4) 木下康民他 : 最新 医学, $14: 1778$, 炤 34 。 - 5) 大鼻研三：日内会

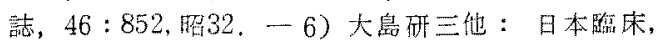

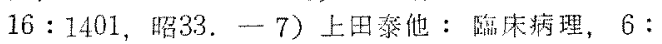
13 , 昭33. - 8) 坂口弘他: 綜合医学, 15:870, 昭 33. - 9) Vernier, R.L. et al.: A.M.A.J. Dis. Child., $96: 306,1958$. 一 10) 土倍田宏治他：日内

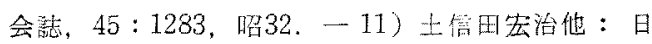

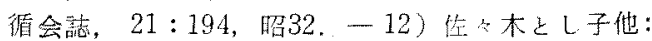

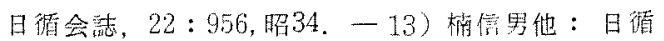
会憙, $23: 110$, 昭34. - 14) Bell, E.T.: Amer. J. Pathol., 12 : 801，1936ょり引用. - 15) Bell, E.T.: Renal Diseases, Lea \& Febiger, Philadelphia, 1950. - 16) Fishberg, A.M.: Hypertension and Nephritis, Lea \& Febiger, Philadel-

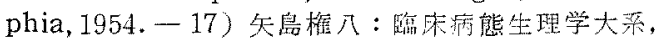

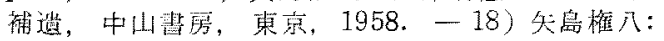

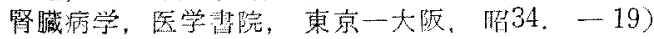

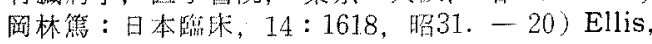
A.: Lancet, $242: 1,1942$. 